\title{
Evaluation of the Photovoltaic System Installation Impact to an Electric Power Grid. Part 1: Simulation of photovoltaic generation by applying a meteorological model
}

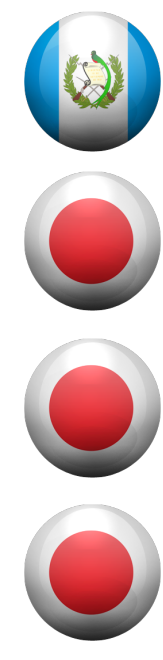

\section{Juan Ernesto Wyss Porras}

BS in Civil Engineering, Masters degree in Economics and Business Administration at Universidad del Valle de Guatemala. Masters degree in Environmental and Renewable Energy Systems and Doctoral Course Student at Gifu University. Antigua Guatemala [Sacatepéquez] Guatemala. <s3815001@edu.gifu-u.ac.jp>. Susumu Shimada

Ph.D degree at Kobe University. Research scientist at AIST in Japan: National Institute of Advanced Industrial Science and Technology, Renewable Energy Research Center. Koriyama [Fukushima] Japan. <susumu.shimada@aist.go.jp>

\section{Jun Yoshino}

Graduate School of Science at Kyoto University. Doctor of Science in Meteorology. Associate Professor, Graduate School of Engineering, Gifu University. Gifu-shi [Gifu] Japan. <jyoshino@gifu-u-ac.jp>

\section{Tomonao Kobayashi}

Professor, Environmental and Renewable Energy Systems, Gifu University. Research field: Applied Meteorology and Ocean Engineering. Especially the application of weather forecasting to renewable energy. Gifu-shi [Gifu] Japan. <kobat@gifu-u.ac.jp>.

\begin{abstract}
The impact of the installation of a large-scale photovoltaic (PV) system to the electric power grid management is analyzed numerically in this series of works. In this part 1 , the solar irradiance at the target country, Guatemala, is evaluated with a weather forecasting model, and PV energy potential is estimated. From the computed potential distribution, the appropriate area for installation of a large-scale PV system is selected. This area is where the solar irradiance is large and the energy consumption regions are close by. The optimal tilted angle of the PV panels is proposed as well from the PV output simulation. The time series data of the PV output is also evaluated in this part, and it will be applied to the analysis of the impact of the PV installation to the electric power grid management in the following part of this series of works.
\end{abstract}

\section{Keywords}

WRF, meteorological model, solar irradiance, PV map, tilted plane. 


\section{Introduction}

Photovoltaic (PV) energy has been expanding rapidly throughout the developed nations around the world. According to the "PV status report 2012" (JÄGER-WALDAU 2012), from the European Commission, the increasing usage of PV energy is due to the creation of new laws promoting its use. Emerging markets in The Americas have also created similar laws, however PV development has not reached such levels. One of major reasons for this is that its output varies due to weather change and the sun's movement, therefore its connection to an electric power grid and the grid management are difficult.

In our research we selected, Guatemala, which is located in the lower latitudes of Central America, as the target for the impact analysis of PV installation. There are several studies on solar energy potential for Guatemala; Bracamonte Orozco (1986) prepared a Guatemala solar map from the field observation data. National Renewable Energy Laboratory (2014) evaluated yearly and monthly averaged Global Horizontal Irradiance (GHI) and Direct Normal Irradiance (DNI), and Perez (2004) also evaluated yearly and monthly GHI. They applied Perez et al. (2002) model which evaluates irradiance from satellite visible images. These prior studies showed the high potential of PV production in Guatemala, and also indicated the regional difference of the potential in this country. However, the PV potential analyses for this country are limited.

In Guatemala, no large scale PV systems had been installed in December 2013. This particular situation is appropriate for a future evaluation of grid management with a large scale PV system. It is also appropriate for the analysis of the comparison of the simulated grid operation with the actual one. In addition, Guatemala has all electric power systems consisting only on one electric power grid, which makes it simple to analyze the grid management.

The variation of the PV output might cause the instability of the electricity supply from the electric power grid. Our research analyzed the effect of installing a PV system to the grid, and consists of two parts. In this Part 1, the solar irradiance and the PV output is computed by the use of a meteorological model and the potential of PV installation is evaluated. The suitable location of a large scale PV system is also discussed here. In the following Part 2 (WYSS PORRAS et al., 2016; soon at this journal: v.10, n.1, 2016), the future grid management including the PV system, and its impacts to the grid are evaluated with a non-linear dynamics model based on the results from this part.

\section{Guatemala as a Target Area}

\subsection{Topography and Weather}

The target country, Guatemala, is located at the low latitude between $14^{\circ} \mathrm{N}$ to $18^{\circ} \mathrm{N}$ in Central America as shown in Figure 1.

The southern plains face the Pacific Ocean and have the mountains called Sierra Madre in the back. The large tract of flat land is in the north. The climate is subtropical and it has the wet season from June to November and the dry season from December to the next May.

\subsection{Current Energy Conditions}

The energy conditions of the target area, Guatemala, is explained briefly here, and will be later explored at Part 2, which will be soon published at this journal (v.10, n.1,2016). At present, Guatemala's

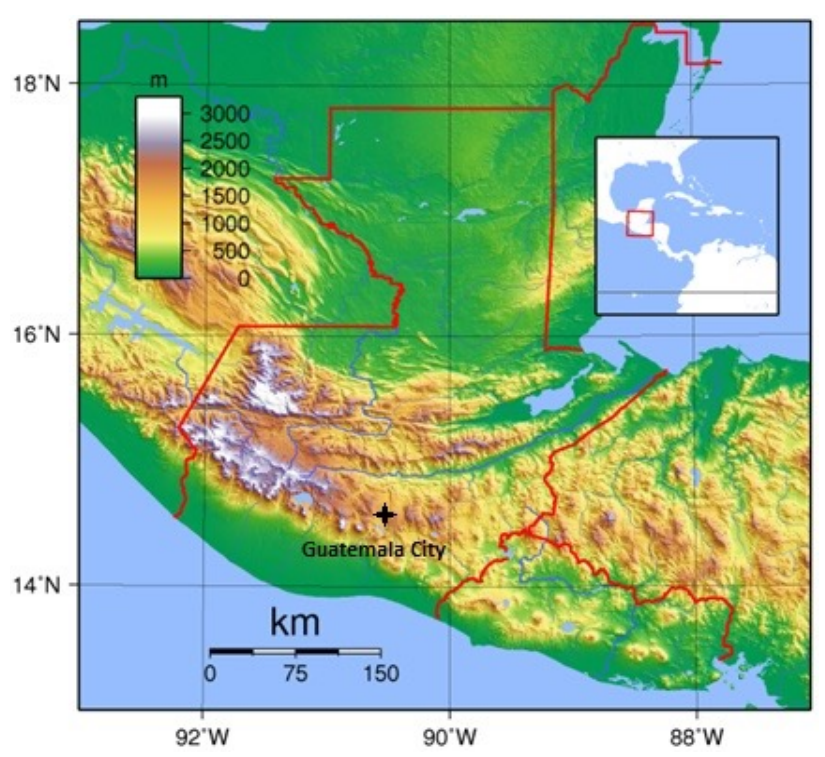

Figure 1. Guatemala's topography (Instituto Geográfico Nacional, Guatemala C.A. 2014). 
energy demand is supplied by a combination of hydro, geothermal, biomass and thermal power plants. Figures 2 and 3 show the installed capacity and energy produced in Guatemala for the year 2013, respectively.

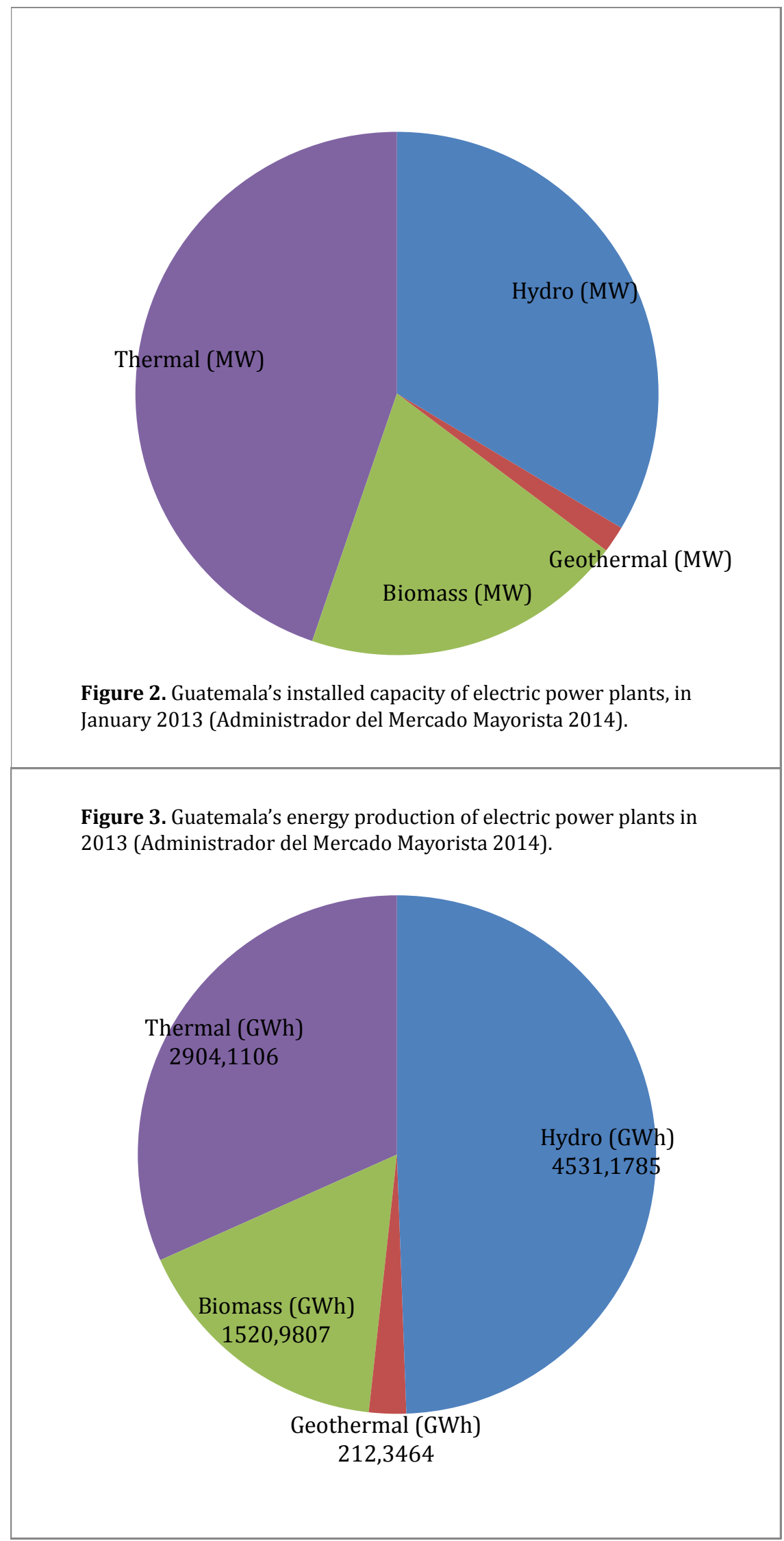


It can be seen from the figures that the country relies heavily on hydro and thermal power plants. They are about one third and $40 \%$ of the installed capacity, and supply about half and one third of the demanded energy, respectively. On the other hand, large-scale PV systems have not been installed into the electric power grid at December 2013, as shown in Figure 2.

\section{Solar Irradiance}

\subsection{Estimation of Solar Irradiance}

PV panel output can be described as a function of power rating, solar irradiance, conversion efficiency, etc. Therefore, its output can be estimated from the meteorological data; the solar irradiance and some other meteorological parameters, like ambient temperature, are required.

Observed irradiance data for Guatemala is limited and it is from only a meteorological station in Guatemala City $\left(14^{\circ} 35^{\prime} 14^{\prime \prime}\right.$ N, $\left.90^{\circ} 31^{\prime} 59^{\prime \prime} \mathrm{W}\right)$, as indicated its location in Figure 1. Furthermore the data sets only included daily and monthly average irradiance. The observed temperatures are only the daily maximum, minimum and average. The present study required hourly irradiance and ambient temperature for one year in the whole country.

\subsection{Meteorological Model}

In order to obtain the time series meteorological data, the numerical model, Weather Research and Forecasting (WRF) is employed. The WRF is developed by the National Oceanic and Atmospheric Administration (NOAA) and the National Center for Atmospheric Research (NCAR) (SKAMAROCK et al., 2008). The WRF is a fully compressible, non-hydrostatic mesoscale meteorological model. This model simulates the weather over the target area including rain, clouds, irradiance and temperature.

Lara-Ganego et al. (2012) use WRF to evaluate the solar irradiance in southern Spain, and showed the advantage of WRF to the application to the PV potential analysis.

\subsection{Computational Conditions}

In order to simulate the weather over the Guatemalan territory, the computational domains are set as shown in Figure 4.

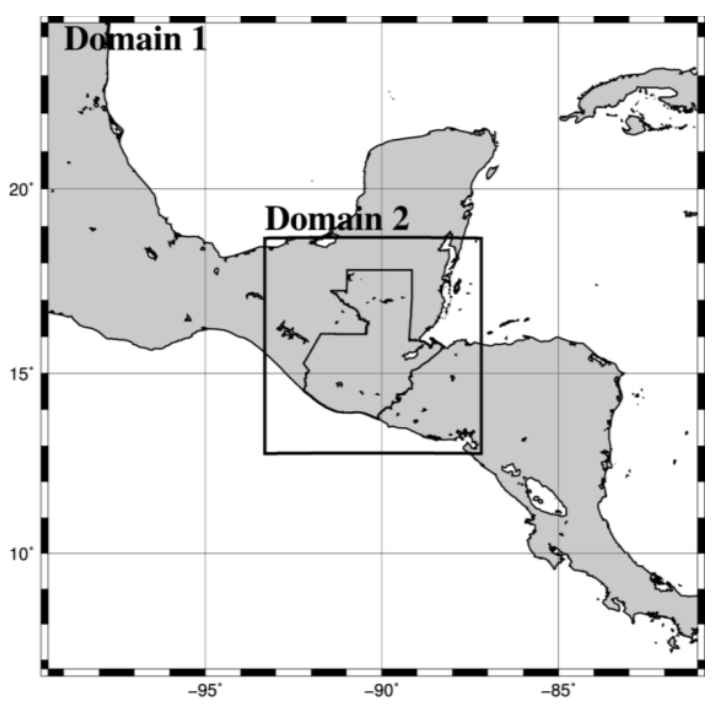

Figure 4. Computational domains for the meteorological model, WRF.

The domains are nested as indicated in the figure. Table 1 shows the computational conditions. The horizontal resolution of the inner domain, Domain 2 is $10 \mathrm{~km}$. This resolution is the same as Perez (2004), and may be acceptable for the potential analysis of PV generation. 
Table 1. WRF model settings for the evaluation of the weather and irradiance in Guatemala.

\begin{tabular}{|l|l|}
\hline \multirow{2}{*}{ Period } & Start: 2011/01/01 00:00:00 UTC \\
& End: 2012/01/01 00:00:00 UTC \\
\hline Input Data & NCEP final analysis (6-hourly, 1 degree x 1 degree) \\
\hline Output Data & 1-hour interval \\
\hline Nesting & 2-way nesting \\
\hline Domain & Domain 01, D01 (30 km, 61 x 61 grids $)$ \\
\hline Vertical layer & Domain 02, D02 (10 km, 61 x 61 grids) \\
\hline FDDA option & Disable \\
\hline
\end{tabular}

The computation period is the complete year 2011. Administrador del Mercado Mayorista (Administrador del Mercado Mayorista 2014) supplies the electric power grid management data in 2011 to us, and we apply it to the analysis of the electric grid management containing PV systems in the following part (WYSS PORRAS et al., 2015). Therefore the target year of this work is fixed in 2011 and the solar irradiance and the meteorological parameters in this year are simulated for the grid management analysis in the following Part 2 (soon in: Labor \& Engenho, v.10, n.1,2016).

The Final Analysis Data released from the National Center for Environmental Prediction (NCEP) (NCAR Data Support Section, Data for Atmospheric and Geosciences Research 2014) is applied for the initial and boundary conditions for the weather computations.

\subsection{Computed Solar Irradiance}

\subsubsection{Irradiance Maps}

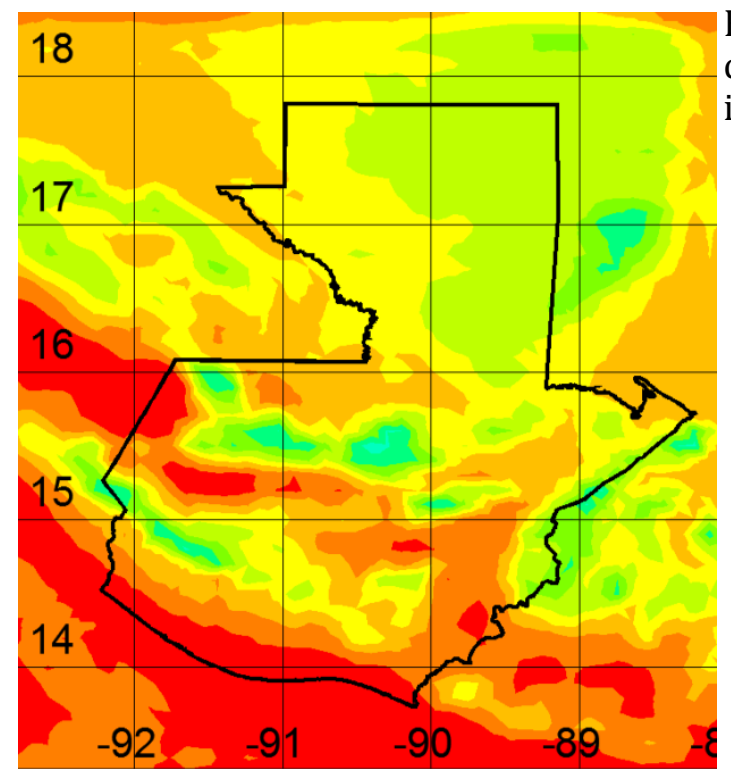

Figure 5 shows the global horizontal irradiance (GHI) calculated with WRF. The GHI in this figure is the daily irradiance averaged in the year 2011.

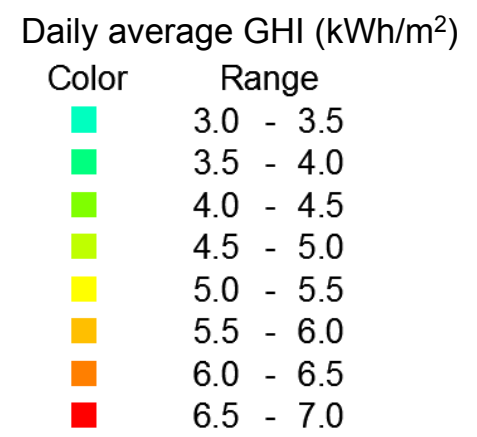

Figure 5. Global horizontal irradiance in Guatemala. Daily irradiance averaged in the year 2011.

The irradiance distribution is discussed here with the geography of the country shown in Figure 1. As it can be seen in Figure 1, there are two mountain chains at the south side of the $16^{\circ} \mathrm{N}$ grid line that cross the country from west to east. These areas have low GHI in the mountains (3.5$\left.4.5 \mathrm{kWh} / \mathrm{m}^{2}\right)$, and high $\left(5.5-7.0 \mathrm{kWh} / \mathrm{m}^{2}\right) \mathrm{GHI}$ in the plateaus in the middle of the mountain ranges. North side of the $16^{\circ} \mathrm{N}$ grid line is a flat area with rain forests and high humidity, where 
GHI is low (4.0-5.0 $\left.\mathrm{kWh} / \mathrm{m}^{2}\right)$. The southern coast facing the Pacific Ocean has high GHI (6.0-7.0 $\mathrm{kWh} / \mathrm{m}^{2}$ ) and is a relatively flat area. Figure 6 shows the yearly GHI in 2011.

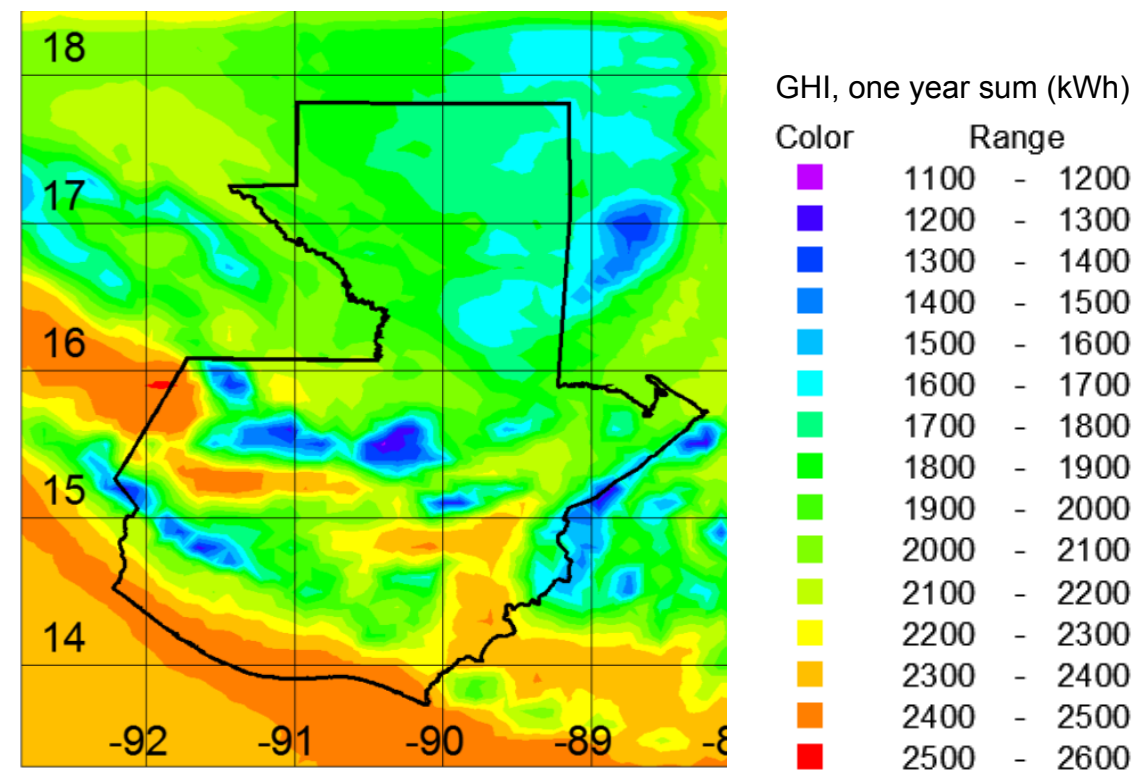

Figure 6. Global horizontal irradiance in Guatemala. Yearly in 2011.

The irradiance in the high GHI area located in the southern coast reaches almost $2.5 \mathrm{MWh}$ in this year.

\subsubsection{Time Series Solar Irradiance}

Figure 7 shows the daily GHI averaged in a week at the meteorological station in Guatemala City in 2011 (Instituto Nacional de Sismología, Vulcanología, Meteorología e Hidrología 2014).

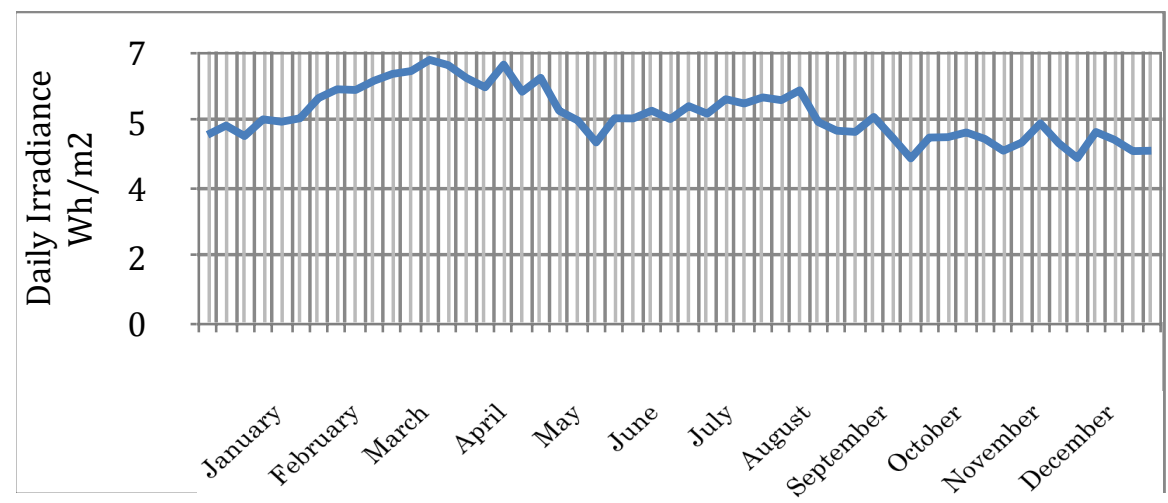

Figure 7. Observed daily Global Horizontal Irradiance at the meteorological station in Guatemala City, averaged in a week (Instituto Nacional de Sismología, Vulcanología, Meteorología e Hidrología 2014).

The station is located in low latitude, the sun passes the zenith at the end of April and the middle of August there. Therefore, if there aren't any effects of the weather to the irradiance, the GHI should be the largest in these months. The figure shows that the higher irradiance is relatively high in the dry season (from December to the next May), particularly from February to April, the irradiance is low due to the cloudy and rainy weather of the wet season. Due to the variations in GHI throughout the year, the daily solar irradiance and also the PV generation is required for the analysis of the grid management in the following Part 2 mentioned previously. The observed daily GHI averaged in each month is compared between the simulated data with the WRF in Figure 8. The WRF estimates the GHI is a little larger than the observations. 


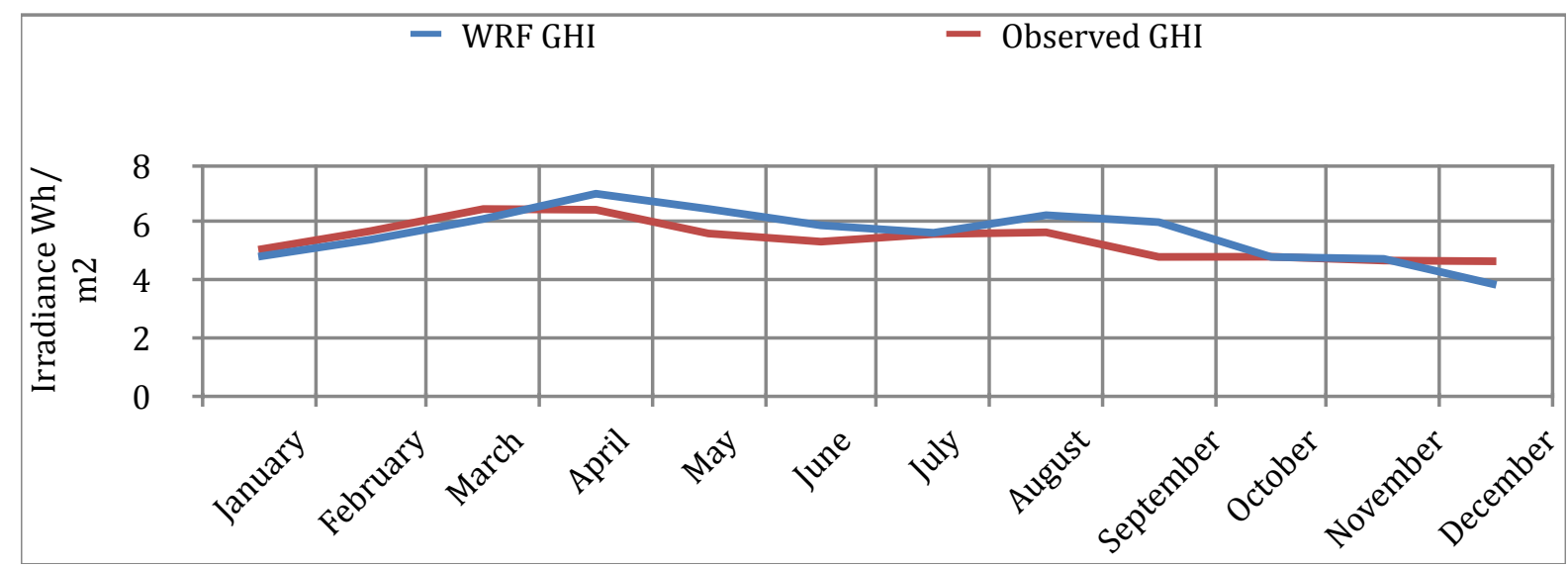

Figure 8. Daily GHI averaged in each month, evaluated with WRF and observed. (Instituto Nacional de Sismología, Vulcanología, Meteorología e Hidrología 2014).

\section{PV Output in Guatemala}

\subsection{PV Output Estimation}

Some meteorological parameters, including global horizontal irradiance (GHI) and ambient temperature, in Guatemala were evaluated by using the meteorological model WRF. The output of a PV system is estimated in this section from the meteorological parameters.

Currently there are many types of PV panels. The crystalline silicon photovoltaic cells account for roughly $80 \%$ to $85 \%$ of the global production according to the U.S. Solar Photovoltaic Manufacturing Industry Trends, Global Competition, Federal Support report (PLATZER, 2012). From the report, the installation of crystalline silicon photovoltaic panels was assumed here.

Huld, et al. (2011) proposes the following equation to evaluate PV output, $P\left(G^{\prime}, T^{\prime}\right)$ for the general crystalline silicon photovoltaic panels.

$$
P\left(G^{\prime}, T^{\prime}\right)=G^{\prime}\left(P_{s t c, m}+k_{1} \ln \left(G^{\prime}\right)+k_{2} \ln \left(G^{\prime}\right)^{2}+k_{3} T^{\prime}+k_{4} T^{\prime} \ln \left(G^{\prime}\right)+k_{5} T^{\prime} \ln \left(G^{\prime}\right)^{2}+k_{6} T^{2}\right)
$$

Where $G^{\prime}$ is the normalized in-plane irradiance, and is computed by dividing the in-plane irradiance $G$ by $1,000 \mathrm{~W} / \mathrm{m}^{2} . T^{\prime}$ is the temperature of the module measured on the standard test conditions. $P_{s t c, m}$ is the power rating of the module; and here, $1 \mathrm{~kW}$ power rating is assumed for the module. The six constants $k_{1}$ to $k_{6}$ were derived empirically from the indoor experiment conducted by these authors and are displayed in Table 2.

Table 2. Constants $k_{1}$ to $k_{6}$ from Huld et al. 2011.

\begin{tabular}{|c|c|}
\hline Constants & Values and dimensions \\
\hline$k_{1}$ & -0.01724 (dimensionless) \\
\hline$k_{2}$ & -0.4047 (dimensionless) \\
$k_{3}$ & $-0.0047\left({ }^{\circ} C^{-1}\right)$ \\
$k_{4}$ & $1.49 \times 10^{-4}\left({ }^{\circ} C^{-1}\right)$ \\
$k_{5}$ & $1.47 \times 110^{-4}\left({ }^{\circ} C^{-1}\right)$ \\
$k_{6}$ & $5.0 \times 110^{-6}\left({ }^{\circ} C^{-1}\right)$ \\
\hline
\end{tabular}


The in-plane irradiance $G$, that reaches the plane with tilted angle $\beta$ is estimated with the following model proposed by Duffie and Beckman's (2006):

$$
G=B_{h} R_{b}(\beta)+D_{h} R_{d}(\beta)+G_{g} \rho R_{r}
$$

Where $B_{h}$ is the direct normal irradiance on the horizontal plane. $D_{h}$ and $G_{g}$ are the diffused and the global horizontal irradiances, respectively. $R_{b}(\beta), R_{d}(\beta)$ and $R_{r}$ are the transposition factors for the direct, the diffused and the reflected irradiances, respectively. $\rho$ is the albedo of the ground.

In this study, the ground reflected irradiance is assumed isotropic, and the following equation (DUFFIE \& BECKMAN 2006) was applied:

$$
R_{r}=(1-\cos \beta) / 2
$$

The albedo $\rho$ varies depending on the surface type and its conditions. Kambezidis, Psiloglou and Gueymard (1994) found that the anisotropic albedo models do not improve the estimation for the solar irradiance on south oriented surfaces, therefore a fixed albedo is used here. A general value of 0.3 is used for the albedo according to Ahrens (2009) since the country is mostly covered in forests and grasslands.

Padovan and Del Col (2010) tested some models available for the estimation of diffused irradiance on the horizontal and tilted planes. They reported that the models proposed by Liu and Jordan (1963), Klucher, (1979), Perez et al. (1990) and Reindl et al. (1990) estimated the diffused irradiance with similar accuracy. The transposition factor for the diffused irradiance on the plane $R_{d}(\beta)$ was estimated by using the following equation proposed by Liu and Jordan (1963):

$$
R_{d}(\beta)=(1+\cos \beta) / 2
$$

Direct irradiance is estimated by Duffie and Beckman (2006) model, which describes the transposition factor for direct irradiance on the plane $R_{d}(\beta)$ as:

$$
R_{d}(\beta)=\cos \theta_{\beta} / \cos \theta
$$

Where $\theta_{\beta}$ and $\theta$ are the solar incidence angles on the plane with the tilted angle $\beta$ and on the horizontal plane, respectively.

The direct and diffused irradiances are estimated by the GHI computed with WRF, and the above models.

Several models to evaluate the direct and diffused irradiances are proposed. And they are analyzed and compared by Khalil and Shaffie (2013). They reported that for south facing surfaces, the models proposed by Perez, et al. (1987), Skartveit, et al. (1987) and Hay (1979) have the most accurate predictions with similar accuracy. Therefore, the model proposed by Skartveit, et al. (1987) was chosen in this paper. It is indicated as follows:

For $G_{g} / G_{0} \leqq 0.22$

$$
r_{D}=1.0-0.09\left(G_{g} / G_{0}\right)
$$




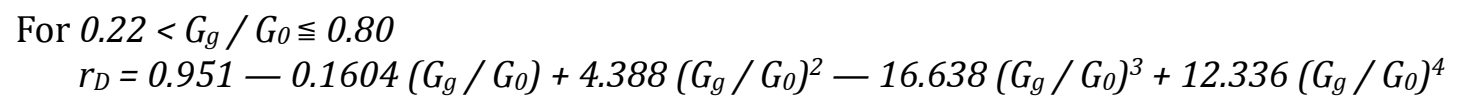

For $G_{g} / G_{0}>0.80$

$$
\begin{gathered}
r_{D}=1.65 \\
D_{h}=G_{g} \times r_{D} \\
B_{h}=G_{g} \times 1 / r_{D}
\end{gathered}
$$

Where $G_{0}$ is the Solar Constant and $r_{D}$ is an empirical parameter estimated by Skartveit and Olseth (1987) in order to calculate the diffused and the direct components of the GHI.

Huld et al. (2011) also proposes the empirical model to evaluate the module temperature $T^{\prime}$ under standard test conditions from the ambient temperature $T_{a m b}$ and the in-plane irradiance $G$ as follows:

$$
\begin{gathered}
T^{\prime}=T_{\text {mod }}-25^{\circ} \mathrm{C} \\
T_{\text {mod }}=T_{\text {amb }}+k_{T} G
\end{gathered}
$$

Where $T_{\text {mod }}$ is the temperature of the module, $T_{a m b}$ is the ambient temperature, $k_{T}$ is a constant related to the panel type, and $G$ is the in-plane irradiance. The typical values of this constant ranges from 0.03 to $0.035^{\circ} \mathrm{C} \mathrm{m}^{2} \mathrm{~W}^{-1}$. This study uses the value $0.035^{\circ} \mathrm{C} \mathrm{m}^{2} \mathrm{~W}^{-1}$, which is the same one used in Huld et al. (2011). The results of these authors from the indoor experiment also showed that Equation 1 predicts the PV output within 1\% error. However, for irradiances lower than $100 \mathrm{~W} / \mathrm{m}^{2}$ the predictions fit within $5 \%$ to $10 \%$ error (HULD et al. 2011).

\subsection{PV Generation and Title Angle}

In order to determine the optimal tilted angle for PV panels in Guatemala, the energy productions are evaluated with different tilted angles from $0^{\circ}$ to $30^{\circ}$, with a $1 \mathrm{~kW}$ installed PV capacity. The target site chosen for this analysis is Guatemala City $\left(14^{\circ} 35^{\prime} 14^{\prime \prime} \mathrm{N}, 90^{\circ} 31^{\prime} 59^{\prime \prime} \mathrm{W}\right)$, which is located in the middle of the country as shown in Figure 1.

Figure 9 shows the relationship between the tilted angle of the panel and the yearly PV energy output.

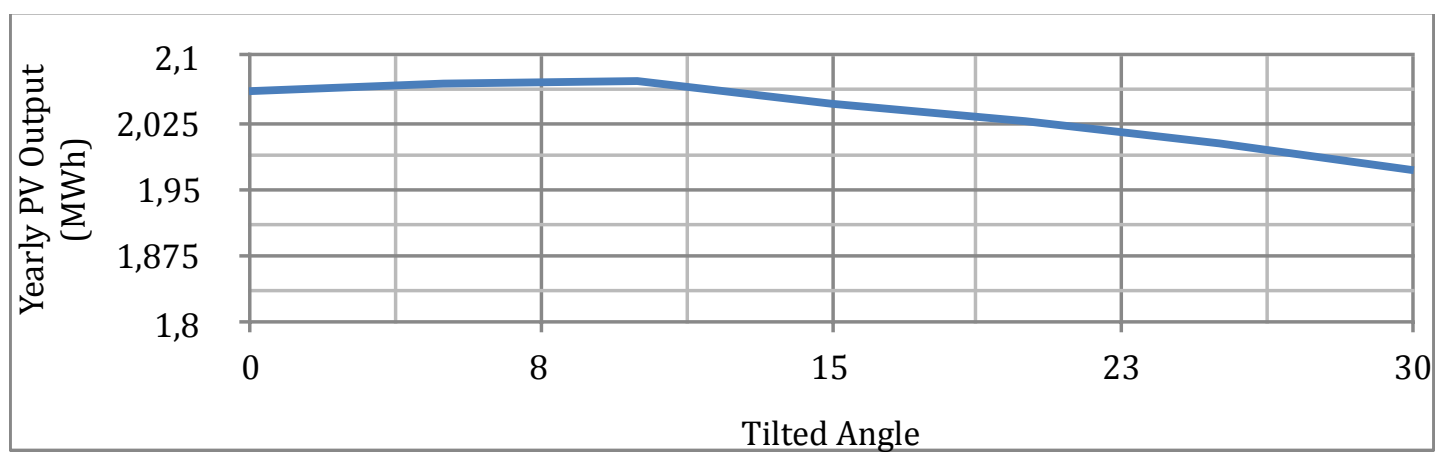

Figure 9. PV output in relationship with tilted angle of a panel (Power rating $1 \mathrm{~kW}$, facing to south).

It shows that the energy production increases moderately from $0^{\circ}$ until reaching its peak at $10^{\circ}$. Afterwards the energy production drops, as the angle becomes larger. From this figure, the angle $10^{\circ}$ is lead as the optimal tilted angle for the solar panels in the target point. 


\subsection{Energy Potential Maps}

The output of the PV system is evaluated in Guatemala with the methods explained above, and it is indicated as the PV potential map as shown in Figure 10. The tilted angle of the PV panels is assumed to be $10^{\circ}$, which is the optimal tilted angle in Guatemala City derived in the previous section. The map shows the estimated total PV output for one year in Guatemala with a power rating $1 \mathrm{~kW}$.

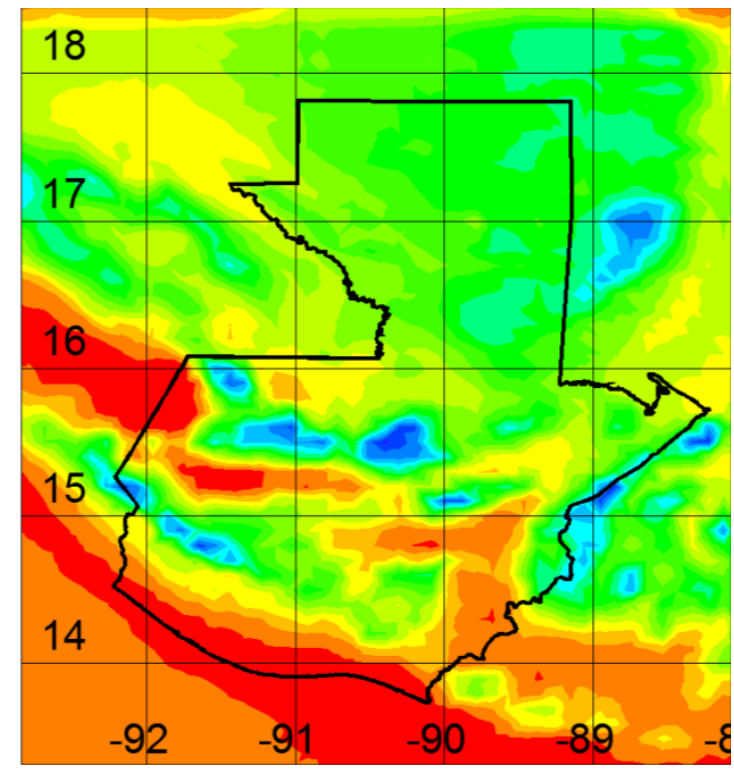

Figure 10. Evaluated PV output in one year. (The system conditions are $1 \mathrm{~kW}$ installed capacity with $10^{\circ}$ tilted panel angle).

The distribution of the PV output in Figure 10 fits well with the irradiance maps in Figures 5 and 6. This is because the tilted angle of the PV panels is small, the irradiance of incidence to the PV panel is similar to the GHI, and the PV output is directly correlated with the solar irradiance. The northern lowlands of Guatemala are flat and humid, which means that cloud coverage commonly occurs throughout the year, and it has effect to both the low irradiance and the small amount of PV output as seen in Figures 6 and 10. The mountain area, which is located to the south side of the $16^{\circ} \mathrm{N}$ grid line in West Guatemala, gets high irradiance as shown in Figure 6 and therefore PV output in that area is also high, as shown in Figure 10. The area along the southern coast, facing the Pacific Ocean, also gets high irradiance and large PV output. The estimated power generation in these areas is about 2.4 to $2.5 \mathrm{MWh}$ per year for a PV system with $1 \mathrm{~kW}$ power rating.

Figure 11 shows the evaluated monthly PV output in Guatemala City $\left(14^{\circ} 35^{\prime} 14^{\prime \prime}\right.$ N, $\left.90^{\circ} 31^{\prime} 59^{\prime \prime} \mathrm{W}\right)$.

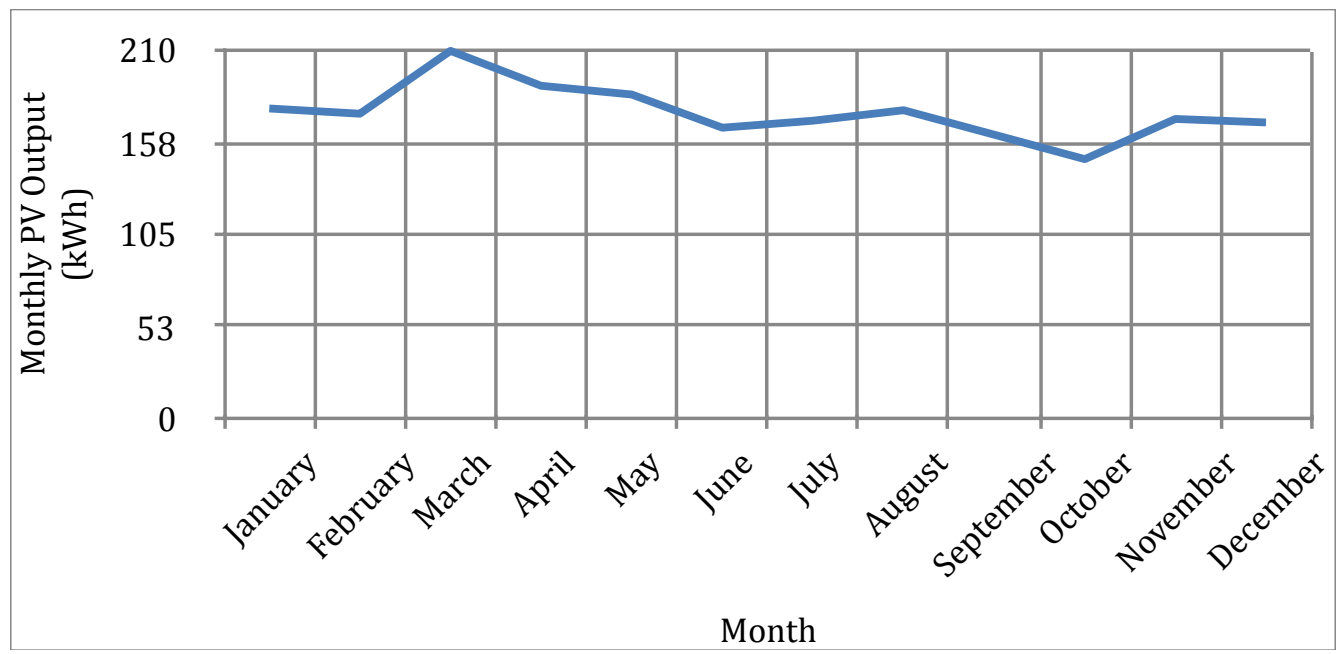

Figure 11. Evaluated Monthly PV output in Guatemala City in 2011. 
The power rating used here is $1 \mathrm{~kW}$ and the tilted angle is $10^{\circ}$. The PV output varies due to the sun's altitude and the weather, and the maximum output reaches $7.83 \mathrm{kWh}$ per day in March.

\section{Appropriate Area for PV Power Plants}

In the previous section, the PV energy potential is evaluated as shown in Figure 10. Based on this result, the appropriate area for large-scale PV power plants is selected. In Figure 10 and the geography map (Figure 1), it is found that the areas along the southern coast facing to the Pacific Ocean and the eastern plateaus connected to Mexico have high potential for PV power generation.

In the present work, the following conditions were applied to evaluate the appropriate area for the PV power plants; high potential area of PV generation, and close to the regions of energy consumption. Figure 12 shows the population distribution in Guatemala (Instituto Nacional de Estadística, Guatemala C.A. 2014).

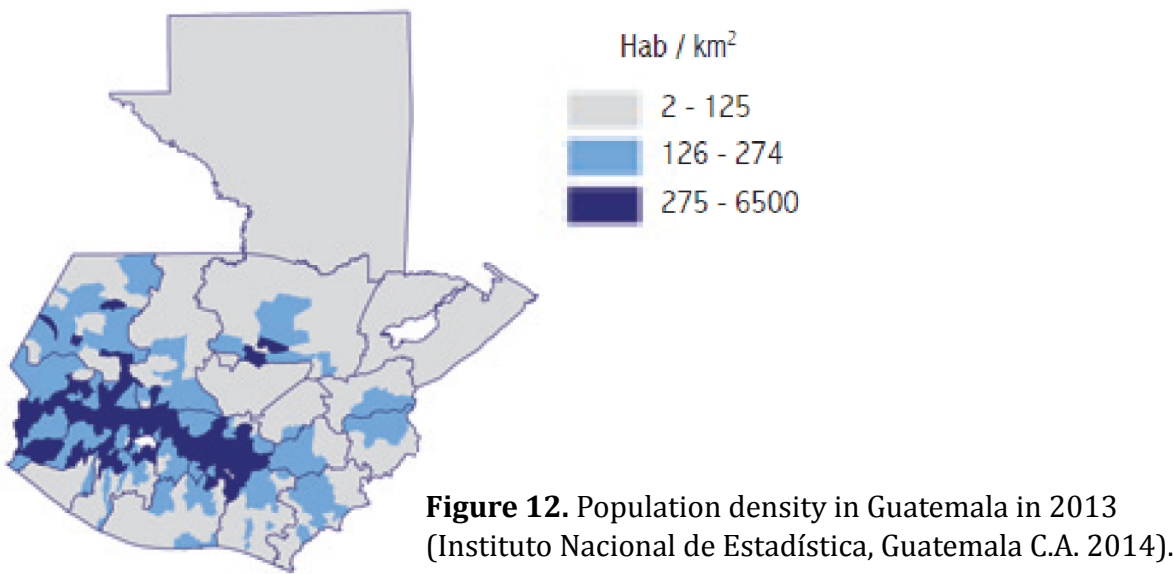

From the conditions for the appropriate site for installing PV system and Figs. 10 and 12, the center of the southern coast is selected. The estimated PV power generation in this site is about 2.4 to $2.5 \mathrm{MWh} /$ year for a PV system with $1 \mathrm{~kW}$ in power rating, and the site is near from the populated area, Guatemala City as shown in Figure 1.

In the following Part 2 (WYSS PORRAS et al., 2016 - to be published in: Labor \& Engenho, v.10, n.1, jan./mar. 2016.) of our research, the energy grid management in Guatemala including PV power plants in this site will be discussed.

\section{Conclusions}

The impact of the installation of a large-scale PV system to the electric power grid was analyzed in the series of our works. Guatemala was selected as the target country because the electric system in it is simple and helpful for the analysis.

In this work, Part 1, the solar irradiance in the target country was computed with the meteorological model WRF and the PV energy potential was evaluated. The southern coast facing the Pacific Ocean has large irradiance and also has high PV energy potential. The maximum irradiance in this area reaches almost 2.5 MWh on the horizontal plane in the selected year. The area is also near the region of energy consumption, and it is a possible area for the large-scale PV power plants development. The optimal tilted angle of the PV panels is also proposed from the PV output simulation.

The evaluated solar irradiance in this work apply to the following work, Part 2 (WYSS PORRAS et al., 2016 — to be published in: Labor \& Engenho, v.10, n.1, jan./mar. 2016 - http://periodicos.bc.unicamp.br/ ojs/index.php/labore/index), for the impact analysis of the installation of a large-scale PV plant to the electric power grid management in this country. 


\section{References}

ADMINISTRADOR del Mercado Mayorista. 2014. "Administrador del Mercado Mayorista, Guatemala C.A." Administrador del Mercado Mayorista. Retrieved December 2014 - http://www.amm.org.gt/

AHRENS, C. D. Meteorology Today: An Introduction to Weather, Climate, and the Environment. Belmont: Brooks/Cole Cengage learning, 2009.

BRACAMONTE OROZCO, Edwin. “Guatemalan Solar Map.” Solar \& Wind Technology 4(No 3):381-388, 1986.

DUFFIE, J. A.; BECKMAN, W.A. Solar Engineering of Thermal. New Jersey: John Wiley \& Sons, Inc., 2006.

HAY, John E. “Calculation of monthly mean solar radiation for horizontal and inclined surfaces”. Solar Energy 23(4):301-307, 1979.

HULD, Thomas; FRIESEN, Gabi; SKOCZEK, Artur; KENNY, Robert P. ; SAMPLE, Tony; Michael FIELD, Michael; DUNLOP, EWAN D. "A power-rating model for crystalline silicon PV modules." Solar Energy Materials and Solar Cells 95(12), 2011.

INSTITUTO GEOGRÁFICO NACIONAL, Guatemala C.A. 2014. "Instituto Geográfico Nacional, Guatemala C.A." Retrieved October 2014 - http://www.ign.gob.gt/

INSTITUTO NACIONAL DE ESTADÍSTICA, Guatemala C.A. 2014. "Instituto Nacional de Estadística, Guatemala C.A.” Retrieved November 2014 — http://www.ine.gob.gt

INSTITUTO NACIONAL DE SISMOLOGÍA, VULCANOLOGÍA, METEOROLOGÍA E HIDROLOGÍA. 2014. “Instituto Nacional de Sismología, Vulcanología, Meteorología e Hidrología, INSIVUMEH”. Retrieved December 2014 — http://www.insivumeh.gob.gt/

JÄGER-WALDAU, Arnulf. 2012. "PV status report 2012.” Joint Research Centre, Institute for Energy and Transport, European Commisision, Luxembourg. Retrieved July 14, 2014 — https://ec.europa.eu/jrc/ — http://re.jrc.ec.europa.eu/refsys/pdf/PV\%20reports/PVReport-2012-Part1.pdf

KAMBEZIDIS, H. D.; PSILOGLOU, B. E.; GUEYMARD, C. "Measurements and models for total solar irradiance on inclined surface in Athens, Greece." Solar Energy 53(2):177-185, 1994.

KHALIL, Samy A.; SHAFFIE, A. M. "A comparative study of total, direct and diffuse solar irradiance by using different models on horizontal and inclined surfaces from Cairo Egypt." Renewable and Sustainable Energy Reviews 27:853-863, 2013.

KLUCHER, T. M. "Evaluation of Models to predict isolation on tilted surfaces." Solar Energy 23(2):111-114, 1979.

LIU, Benjamin Y. H.; JORDAN, RICHARD C. "The long-term average performance of flat-plate solar energy collectors." Solar Energy 7(2):249-256, 1963.

NATIONAL RENEWABLE ENERGY LABORATORY. 2014. “National Renewable Energy Laboratory” Retrieved December 2014 — http://www.nrel.gov/

NCAR Data Support Section, Data for Atmospheric and Geociences Research. 2014. “CISL Research Data Archive". Retrieved November 2014 — http://rda.ucar.edu/datasets/ds083.2/

PADOVAN, Andrea; DEL COL, Davide. "Measurement and modeling of solar irradiance components on horizontal and tilted planes." Solar Energy 84(12):2068-2084, 2010. 
PEREZ, Richard. 2004. "Solar: hourly solar (direct normal (DNI), global horizontal (GHI), and diffuse) data for selected stations in Guatemala from State University of New York." OpenEI, Open Energy Information. Retrieved December 2014 - http://en.openei.org/datasets/dataset/solar-hourly-solardirect-normal-dni-global-horizontal-ghi-and-diffuse-data-for-selected-s7

PEREZ, Richard; INEICHEN, Pierre; SEALS, Robert; MICHALSKY, Joseph ; STEWART, Ronald. "Modeling daylight availability and irradiance components from direct and global irrdiance." Solar Energy 44(5): 271-289, 1990.

PEREZ, Richard; SEALS, Robert; INEICHEN, Pierre; STEWART, Ronald; MENICUCCI, David. "A new simplified version of the perez diffuse irradiance model for tilted surfaces". Solar Energy 39(3):221-231, 1987.

PLATZER, Michaela D. “U.S. Solar Photovoltaic Manufacturing: Industry Trends, Global Competition, Federal Support". 2012.

REINDL, D. T.; BECKMAN, W. A.; DUFFIE, J. A. "Evaluation of hourly tilted surface radiation models." Solar Energy 45(1):9-17, 1990.

SKAMAROCK, William C.; KLEMP, Joseph B.; DUDHIA, Jimy; GILL, David O.; BARKER, Dale M.; DUDA, Michael G.; HUANG, Xiang-Yu; WANG, Wei; POWERS, Jordan G. 2008. A Description of the Adavanced Research WRF Version 3. Boulder [Colorado] United States: Mesoscale and Microscale Meteorology Division, National Center for Atmospheric Research. 2008.

SKARTVEIT, Arvid; OLSETH, Jan A. 1987. "A model for the diffuse fraction of hourly global radiation." Solar Energy 38(4):271-274, 1987.

WYSS PORRAS, Juan E.; SHIMADA, Susumu; YOSHINO, Jun; KOBAYASHI, Tomonao. 2015. "Evaluation of the Photovoltaic System Installation Impact to Guatemala's Electric Power Grid; Part 2: Impact analysis of photovoltaic installation to an electric power grid by applying a non linear analysis model". Labor \& Engenho 10(1), 2016 (To be published) — http://periodicos.bc.unicamp.br/ojs/index.php/labore/index 